\title{
Fibromiyalji Sendromu ile Bağırsak Mikrobiyotası Arasındaki İlişkinin Araştırılması
}

\section{Investigating of Relation Between Fibromyalgia Syndrome and Intestinal Microbiota}

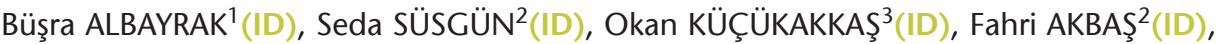 \\ Ayşegül YABACl ${ }^{4}(I D)$, Semra ÖZÇELIK ${ }^{5,6}($ ID) \\ ${ }^{1}$ Bezmialem Vakıf Üniversitesi Tıp Fakültesi, İstanbul. \\ ${ }^{1}$ Bezmialem Vakif University, Faculty of Medicine, Istanbul, Turkey. \\ 2 Bezmialem Vakıf Üniversitesi Tıp Fakültesi, Tıbbi Biyoloji Anabilim Dalı, İstanbul. \\ 2 Bezmialem Vakif University, Faculty of Medicine, Department of Medical Biology, Istanbul, Turkey. \\ ${ }^{3}$ Bezmialem Vakıf Üniversitesi Tıp Fakültesi, Fiziksel Tıp ve Rehabilitasyon Anabilim Dalı, İstanbul. \\ ${ }^{3}$ Bezmialem Vakif University, Faculty of Medicine, Department of Physical Medicine and Rehabilitation, Istanbul Turkey. \\ ${ }^{4}$ Bezmialem Vakıf Üniversitesi Tıp Fakültesi, Biyoistatistik ve Bilişim Anabilim Dalı, İstanbul. \\ ${ }^{4}$ Bezmialem Vakif University, Faculty of Medicine, Department of Biostatistics and Informatics, Istanbul Turkey. \\ ${ }^{5}$ Bezmialem Vakıf Üniversitesi Sağlık Hizmetleri Meslek Yüksekokulu, Tıbbi Laboratuvar Teknikleri Programı \\ Anabilim Dalı, i̇stanbul. \\ ${ }^{5}$ Bezmialem Vakif University, Vocational School of Health Services, Medical Laboratory Techniques Programme, \\ Istanbul, Turkey. \\ ${ }^{6}$ Bezmialem Vakıf Üniversitesi, Sağlık Bilimleri Enstitüsü, İstanbul. \\ ${ }^{6}$ Bezmialem Vakif University, Institute of Health Science, Istanbul, Turkey.
}

Makale Atıfı: Albayrak B, Süsgün S, Küçükakkaş O, Akbaş F, Yabacı A, Özçelik S. Fibromiyalji sendromu ile bağırsak mikrobiyotası arasındaki ilişkinin araştırılması. Mikrobiyol Bul 2021;55(2):146-160.

\section{ÖZ}

Fibromiyalji sendromu (FMS), yetişkin popülasyonda bildirilen prevalansı \%3-10 olan, kronik yaygın ağrının sık görülen formlarından biridir. Tipik ağrının klinik görünümü ve ilişkili somatik ve psikolojik semptomların varlığı tanıya temel oluşturur. FMS sinir sistemi disfonksiyonu ile ilişkilidir ve nörotransmitterler fibromiyalji için onaylanmış bir dizi ilacın hedefi olarak rol oynamaktadır. Bununla birlikte, FMS'de altta yatan mekanizmalar kesin olarak henüz bilinmemekle birlikte birçok hipotez ortaya konmuştur. Fibromiyalji ve irritabl bağırsak sendromu (IBS) arasındaki ilişki göz önüne alındığında, değişen bağırsak mikrobiyomu fibromiyalji ile ilişkili olabilir. Bu çalışmada, FMS tanılı hastalarda sağlıklı kontrollere göre değişen bağırsak mikrobiyom düzeylerinin araştırılması amaçlanmıştır. Mikrobiyom çalışması için FMS tanılı 54 hastadan ve 36 sağlıkı kişiden oluşan kohorttan fekal örnekler toplanmıştır. Kontrol grubunda herhangi bir mental ve/veya fiziksel hastalığı olanlar çalışma dışında bırakılmıştır. FMS'li hasta grubu, "American College of Rheumatology (ACR)" 2010 tanı kriterlerine bağıl kalınarak belirlenmiştir. Fekal örnekler, kullanılana kadar $-80^{\circ} \mathrm{C}^{\prime}$ de muhafaza edilmiş ve buz üzerinde çözülmüş; her ekstraksiyon için 0.3 $\mathrm{g}$ feçes tartılmıştır. DNA izolasyonu, ticari kit ile üreticinin protokolüne uygun olarak gerçekleştirilmiştir. Örnekler, gerçek zamanlı polimeraz zincir yöntemi ile Bacteroidetes, Firmicutes, Enterobacter, Lactobacillus, Streptococcus ve Bifidobacterium'a özgül primerler ile 16S rRNA gen amplifikasyonu yapılarak karşılaştırılmıştır. Sonuçlara göre, hasta grubunda Bacteroidetes ve Bifidobacterium istatistiksel olarak anlamlı bir 
şekilde artarken $(p<0.05)$, Firmicutes'in azaldığı saptanmıştır $(p<0.001)$. Enterobacter, Streptococcus ve Lactobacillus için istatistiksel olarak anlamlı sonuç bulunamamıştır ( $p>0.05)$. Bakteriler arasındaki ilişki değerlendirildiğinde, Bacteroidetes ile Firmicutes yüzdesi arasında istatistiksel olarak yüksek anlamlı ve negatif korelasyon bulunurken $(r=-0.778, p<0.001)$, Enterobacter ve Bifidobacterium yüzdesi arasında orta derecede istatistiksel anlamlılık ve pozitif korelasyon gözlenmiştir $(r=0.460, p=0.005)$. Sonuçlar, bağırsak mikrobiyotasının fibromiyaljide rol oynayabileceğini göstermektedir. Bağırsaktaki Firmicutes ve Bacteroidetes filumlarının dengesinin bağırsak homeostazı için önemli etkilere sahip olduğu bilinmektedir. Özetle, daha büyük kohortlarda yapılacak büyük ölçekli araştırmaların, bağırsak mikrobiyomu ve FMS arasındaki ilişkiyi anlamada ve olası tedavi seçeneklerini değerlendirmede etkili olacağı açıktır.

Anahtar kelimeler: Fibromiyalji sendromu; Bacteroidetes; Firmicutes; Bifidobacterium; mikrobiyota.

\section{ABSTRACT}

Fibromyalgia syndrome (FMS) is one of the most frequent forms of chronic widespread pain, with a reported prevalence of $3-10 \%$ in the adult population. Clinical presentation of the typical pain and the presence of associated somatic and psychological symptoms form the basis of the diagnosis. FMS is associated with nervous system dysfunction and neurotransmitters act as targets of a number of drugs approved for fibromyalgia. However, although the underlying mechanisms in FMS are not yet known precisely, many hypotheses have been put forward. Considering the relation between fibromyalgia and irritable bowel syndrome (IBS), altered gut microbiome could be associated with fibromyalgia. In this study, it was aimed to investigate the variation of intestinal microbiome levels in patients with FMS compared to healthy controls. For the investigation of the microbiome, fecal samples were collected from a cohort of 54 patients with FMS and 36 healthy individuals. Those with any mental and/or physical illness in the control group were excluded from the study. The FMS patient group was determined according to the "American College of Rheumatology (ACR)" 2010 diagnostic criteria. The fecal samples were stored at $-80^{\circ} \mathrm{C}$ until use and were thawed on ice; for each extraction, $0.3 \mathrm{~g}$ of faeces were weighed. Extraction of DNA was carried out with commercial kit according to the manufacturer's recommendations. Samples were compared using 16S rRNA gene amplification with specific primers of Bacteroidetes, Firmicutes, Enterobacter, Lactobacillus, Streptococcus and Bifidobacterium by the real-time PCR method. According to our results, while the increase of Bacteroidetes and Bifidobacterium was statistically significant $(p<0.05)$, Firmicutes decreased $(p<0.001)$ in the patient group. No statistically significant results were found for Enterobacter, Streptococcus and Lactobacillus ( $p>0.05$ ). When the relationship between bacteria was evaluated, a high statistically significance and negative correlation was found between Bacteroidetes and the percentage of Firmicutes $(r=-0.778, p<0.001)$, while a moderate statistical significance and positive correlation was observed between the percentage of Enterobacter and Bifidobacterium $(r=0.460, p=0.005)$. The results suggest that the gut microbiota may play a role in fibromyalgia. The balance of Firmicutes and Bacteroidetes phyla in the gut is known to have important effects on intestinal homeostasis. In summary, it is clear that large-scale further research in larger cohorts will be effective in understanding the relationship between the gut microbiome and FMS and evaluating possible treatment options.

Keywords: Fibromyalgia syndrome; Bacteroidetes; Firmicutes; Bifidobacterium; microbiota.

\section{Giriş}

Fibromiyalji sendromu (FMS), kas-iskelet sisteminde kronik, yaygın ağrı ve sertlik; fizik muayenede palpasyonla ağrılı hassas noktaların belirlenmesi ile karakterize olan ve özgül laboratuvar bulguları olmayan bir hastalıktır ${ }^{1}$. FMS tanılı hastalarda fonksiyonel bozukluklar, dirençli yorgunluk, uyku bozuklukları, bilişsel bozukluklar, irritabl bağırsak sendromu (IBS), parestezi ve duygudurum bozukluğu da mevcuttur². FMS, en yaygın ikinci "romatizmal" hastalıktır. Bazı araştırmalar FMS'nin genel popülasyonun \%3-10'unu etkilediğini göstermiştir ${ }^{3}$. FMS prevalansı yaşla birlikte artmaktadır ve sıklıkla 40-60 yaş aralığındaki kadınlarda gözlenmektedir ${ }^{4-6}$. 
FMS'nin patofizyolojisinde çeşitli mekanizmalar yer almaktadır. FMS, merkezi sinir sisteminde duyarlıık, nöroendokrin ve otonom sinir sistemi disfonksiyonu ile ilişkilidir. Hastalarda mekanik, termal ve elektriksel uyarılara karşı psiko-fizyolojik hiperaljezi bulguları görülmektedir. Bu durum hem merkezi hem de periferik sistemde nosiseptif anomali varsayımına yol açar ${ }^{7}$. Buna karşın enflamatuvar yumuşak doku anomalilerine dair tutarlı bir kanıt bulunmamış olması, FMS'nin etiyopatolojisinde merkezi sinir sisteminin (MSS) önemini ortaya çıkarmaktadır ${ }^{8,9}$. Merkezi sinir sistemi duyarlılık sendromu olan birçok hastada belirgin hiperaljezi ve/veya allodini görülebilmektedir ${ }^{10}$. FMS hasta grubu ile sağlıklı kontrol grubunun karşılaştırıldığı bir çalışmada ${ }^{11}$, FMS'li hastaların düşük seviyede sayılabilecek basınç değerlerinde bile $\left(2.4 \mathrm{~kg} / \mathrm{cm}^{2}\right)$ kontrol grubuna göre yüksek düzeyde serebral aktivasyon ortaya çıkardığı izlenmiştir. Bu durum, FMS'li hastalara uygulanan etkinin kortikal veya subkortikal düzeyde ağrının algılanmasında artışa neden olduğu hipotezini güçlendirmektedir.

FMS'de bir yaklaşım da nörotransmitter disfonksiyonudur. FMS grubu ile yapılan bir çalışmada beyin omurilik sıvısında P maddesinin kontrol grubuna oranla üç kat daha yüksek olduğu bildirilmiştir. Ek olarak, FMS'li hastalarda serum serotonin düzeylerinin önemli ölçüde düşük olduğunu gösteren çalışmalar da mevcuttur ${ }^{12,13}$.

Son yıllarda yapılan araştırmalarda ise, FMS ile bağırsak mikrobiyotası arasında ilişki olabileceği düşünülmektedir. Fibromiyalji ve IBS'nin birlikteliği düşünüldüğünde bu yaklaşım araştırmaya değer bir alan olarak görülmektedir. IBS'de bağırsak mikrobiyomu bileşiminde ve çeşitliliğinde değişiklikler bildirilmiştir ancak bu ilişki fibromiyaljide tam olarak anlaşılmamıştır ${ }^{14}$. Bağırsak mikrobiyotası ile insan fizyolojisi arasındaki bağlantı düşünüldüğünde çoğu hastalığın sağlıklı bağırsak mikrobiyotasının bozulması sonucu ortaya çıktığı öne sürülmektedir ${ }^{15}$. Literatürde bağırsak mikrobiyotasının bileşimindeki değişikliklerin gastrointestinal, metabolik, otoimmün, alerjik ve nöropsikiyatrik bozukluklarla ilişkili olduğu birçok çalışmada gösterilmiştir ${ }^{16}$.

Ayrıca insan bağırsak mikrobiyomu, beyin sağlığını birçok yönden etkileyebilir; lipopolisakkaritler gibi bakteri yapısal bileşenleri bağışıklık sistemine düşük tonik uyarılar yapabilir; ince bağırsakta bakterilerin aşırı çoğalması veya bağırsak geçirgenliğinin artması sonucu oluşan bakteriyel disbiyoz, MSS'de enflemasyonun uyarılmasına neden olabilir. Diğer bir mekanizma da bakteriyel proteinlerin insan antijenleri ile etkileşerek adaptif bağışıklık sistemini uyarması ve bunun sonucunda disfonksiyonel yanıtlara neden olmasıdır. Ayrıca D-laktik asit ve amonyak gibi nörotoksik metabolitler, bakteriyel enzimler tarafından üretilebilir. Nörotoksisite, kısa zincirli yağ asitleri gibi uygun metabolitler tarafından da oluşabilir. Yapılan araştırmalar, mikrobiyotanın enterik sinir sisteminin afferent nöronlarını vagus siniri yoluyla beyne sinyaller göndermek için doğrudan aktive ettiğini göstermektedir. Bu farklı yollar boyunca, bağırsak mikrobiyomu hipotalamik-hipofiz-adrenal eksenin uyku ve stres reaktivitesini etkilemektedir. Sonuç olarak, bağırsak mikrobiyomu; hafızayı, davranışı ve bilişsel işlevleri etkileyebilir ve bu özelliğiyle birçok durum ve hastalık için önemlidir ${ }^{17}$. 
Bu çalışmada FMS etiyopatogenezinde bağırsak mikrobiyotasının önemi, FMS tanılı hastalarda mikrobiyom karakteristiğinin ve disbiyoz nedenlerininin sağlıklı kontrollerle karşılaştırarak ortaya konması amaçlanmıştır.

\section{GEREÇ ve YÖNTEM}

$\mathrm{Bu}$ çalışma, Bezmialem Vakıf Üniversitesi Girişimsel Olmayan Klinik Araştırmalar Etik Kurulu onayı ile gerçekleştirildi (Tarih: 16.10.2018, Karar No: 19/252). Helsinki Deklarasyonu'nun etik kurallarına uygun olarak ve tüm katılımcılardan yazılı bilgilendirilmiş onam formları alınarak çalışılmıştır.

\section{Çalışma Kohortunun Belirlenmesi}

30 Şubat-30 Haziran 2019 tarihleri arasında Fiziksel Tıp ve Rehabilitasyon Anabilim Dalına başvuran fibromiyalji tanısı almış 54 hasta çalışmaya dahil edildi. FMS grubu, hasta raporuna göre ağrı semptomları ile ağrının yeri ve boyutunu baz alan "American College of Rheumatology (ACR)" 2010 yılı tanı kriterleri göz önünde bulundurularak çalışmaya dahil edildi ${ }^{18}$. Kontrol grubuna herhangi bir mental ya da fiziksel rahatsızlığı olmayan bireyler dahil edildi.

Ek olarak 30 yaş altı ve 60 yaş üstü bireyler, son üç ayda bağırsak mikrobiyotasını etkileyen ilaçlar, antibiyotikler, yüksek dozlarda probiyotikler ve biyolojik ajanlar kullanan bireyler ve son altı ayda önemli diyet değişiklikleri yaşayan bireyler çalışmadan dışlandı.

Çalışmaya dahil edilen tüm bireylerden anamnez alıntı ve FMS'li hastalar için hazırlanmış olan fibromiyalji etki anketi (FIQ) dolduruldu. FIQ skorlaması; hasta raporları, fonksiyonel durum verileri ve klinik gözlemlerden derlenen bilgilerden geliştirilmiş bir sistemdir. Bu sistemde son bir hafta içinde fiziksel fonksiyonlar, çalışma durumu (iş yükü ve çalışılamayan günlerin varlığı), depresyon, anksiyete, sabah yorgunluğu, ağrı ve sertlik, bitkinlik durumu ve iyi hissedilen günler değerlendirilmektedir.

\section{S rRNA için Kantitatif Polimeraz Zincir Reaksiyonu Amplifikasyonu}

FMS tanısı almış 54 bireyden ve sağlıklı 36 bireyden fekal örnekler toplanıp $-80^{\circ} \mathrm{C}^{\prime} \mathrm{de}$ saklandı. Çalışma sırasında örnekler buz üzerinde çözülerek her biri için $0.3 \mathrm{~g}$ feçes tartıldı. DNA izolasyonu EZ-10 Spin Column Soil ve Fecal DNA Miniprep Kit (Bio Basic, Markham ON, Kanada) ile üreticinin protokolüne uygun olarak gerçekleştirildi. DNA izolasyonunun son basamağı olan elüsyon $100 \mu$ l olarak yapıldı; örnekler polimeraz zincir reaksiyonu (PCR) aşamasına kadar $-20^{\circ} \mathrm{C}^{\prime}$ de saklandı. DNA'ların kalitatif ve kantitatif değerlendirmeleri Multiskan GO (Thermo Fisher Scientific, Massachusetts, ABD) cihazı ile yapıldı. Kantitatif gerçek zamanlı PCR (qRt-PCR) çalışmaları SensiFast SYBR No-ROX (Bioline, Londra, İngiltere) kullanılarak Bio-Rad CFX96 (Bio-Rad, ABD) cihazında gerçekleştirildi ve eşik değer döngü değerleri (Ct) analiz için kullanıldı. Her bir primer için qRt-PCR aşamasına geçilmeden önce konvansiyonel gradiyent PCR yöntemi uygulandı ve \%2'lik agaroz jelde yürütülerek uygun erime sıcaklıkları tespit edildi (Şekil 1). Bakteriye özgül 16S rRNA primerleri ve belirlenen bağlanma sıcaklıkları Tablo I'de verilmektedir ${ }^{19-22}$. Amplifikasyon koşulları; $95^{\circ} \mathrm{C}^{\prime}$ de 5 dakika ve takiben 40 döngü olacak şekilde $95^{\circ} \mathrm{C}^{\prime}$ de 10 saniye, 55 - 


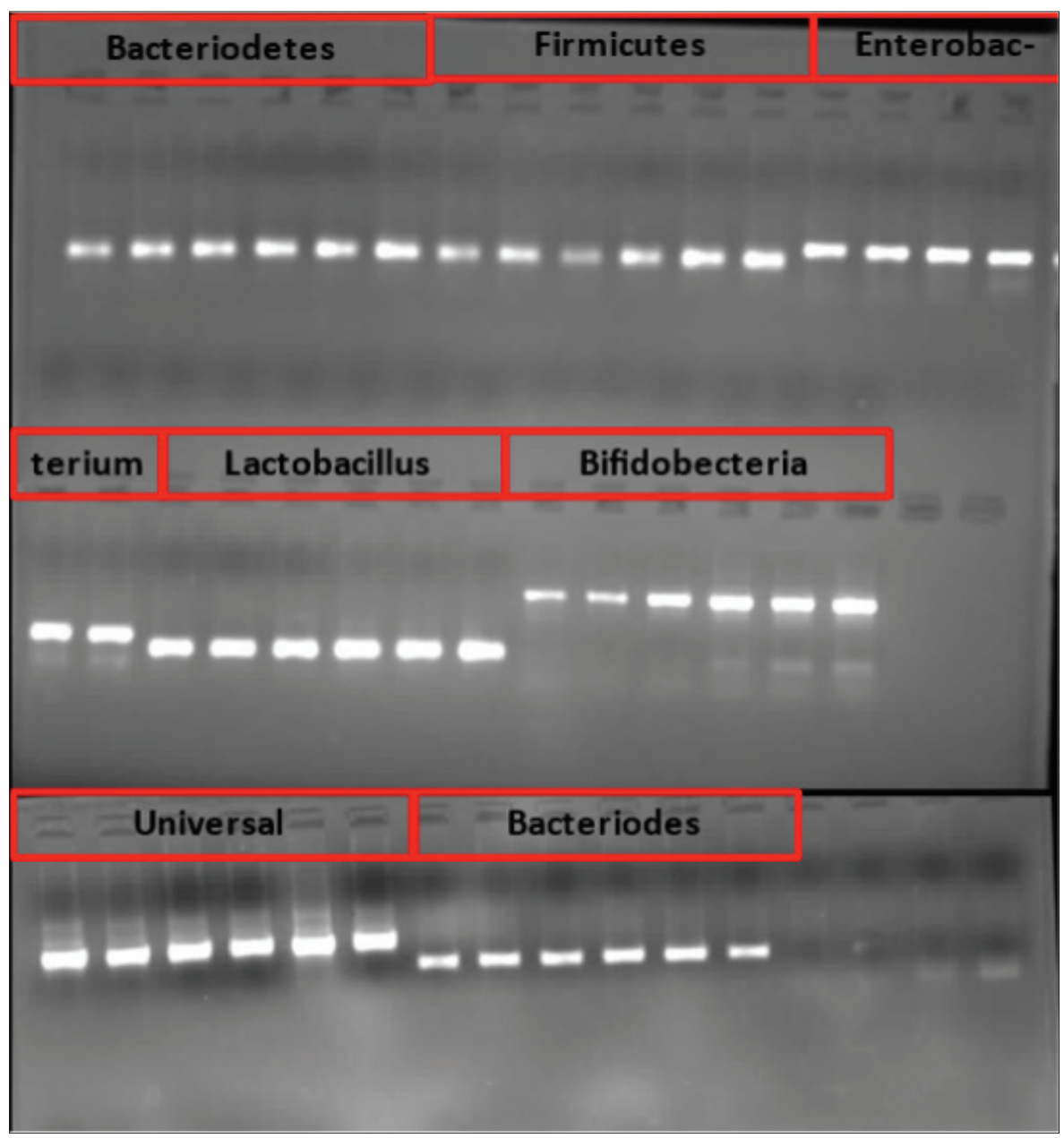

Şekil 1. Konvansiyonel gradiyent polimeraz zincir reaksiyonu jel görüntüleri.

$60^{\circ} \mathrm{C}^{\prime}$ de 7 saniye, $72^{\circ} \mathrm{C}^{\prime}$ de 5 saniye şeklinde uygulandı. Ek olarak, özgül amplifikasyon ürününden elde edilen floresan sinyalini artefaktlardan ayırt etmek için qRt-PCR'den sonra erime eğrisi analizi gerçekleştirildi. Erime eğrileri, $65^{\circ} \mathrm{C}^{\prime}$ den $95^{\circ} \mathrm{C}^{\prime}$ ye yavaş ısıtmayla elde edildi ve her $0.5^{\circ} \mathrm{C}$ sıcaklık artışında floresan ölçümleri saptandı (Şekil 2).

Elde edilen hedef bakteriye ait $\mathrm{Ct}$ değerleri, universal dizi $\mathrm{Ct}$ değerleri kullanılarak normalize edildi ardından hasta grubu ile kontrol grubu arasında karşılaştırma yapıldı. Bakteriyel taksonların 16S rRNA sekanslarını kodlayan gen hedeflerinin göreceli miktarları ve göreceli oranları sırasılyla $2^{-\Delta \Delta C T}$ ve $2^{\Delta C T}$ (taksa örneği)/2 $2^{\Delta C T}$ (toplam bakteri) değerleri kullanılarak hesaplandı.

Verilerin dağılımı Shapiro Wilk testi ile incelendi. Normal dağılıma sahip değişkenlerin ortalamaları arasındaki fark bağımsız örneklem $t$ testi ile, parametrik olmayan dağılıma 


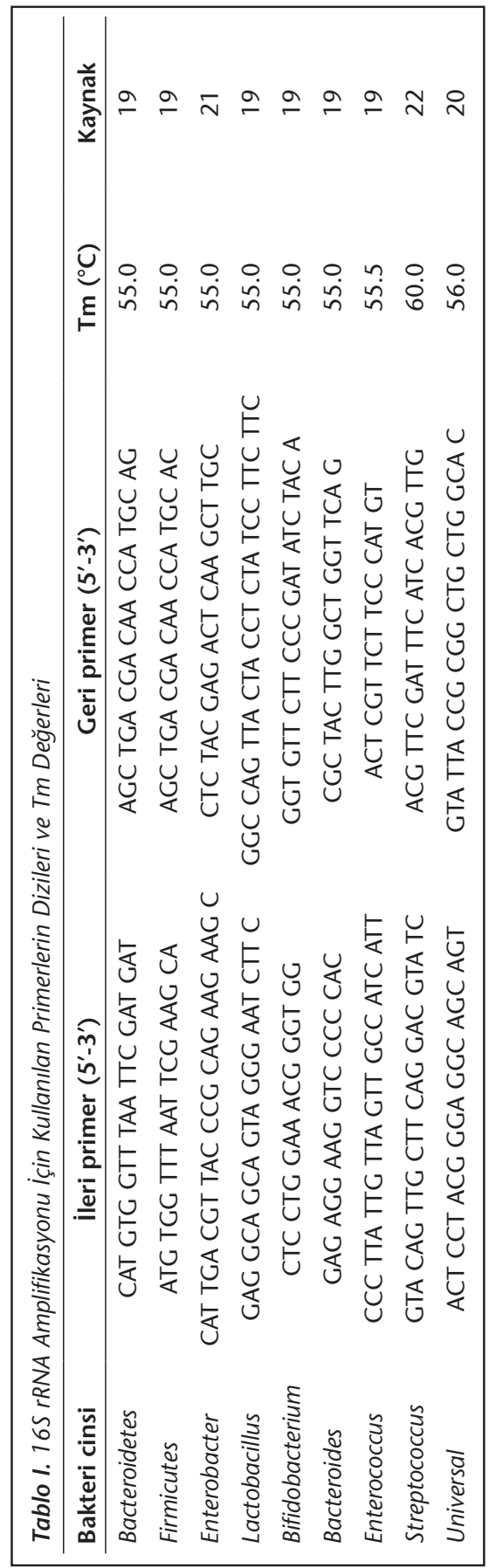




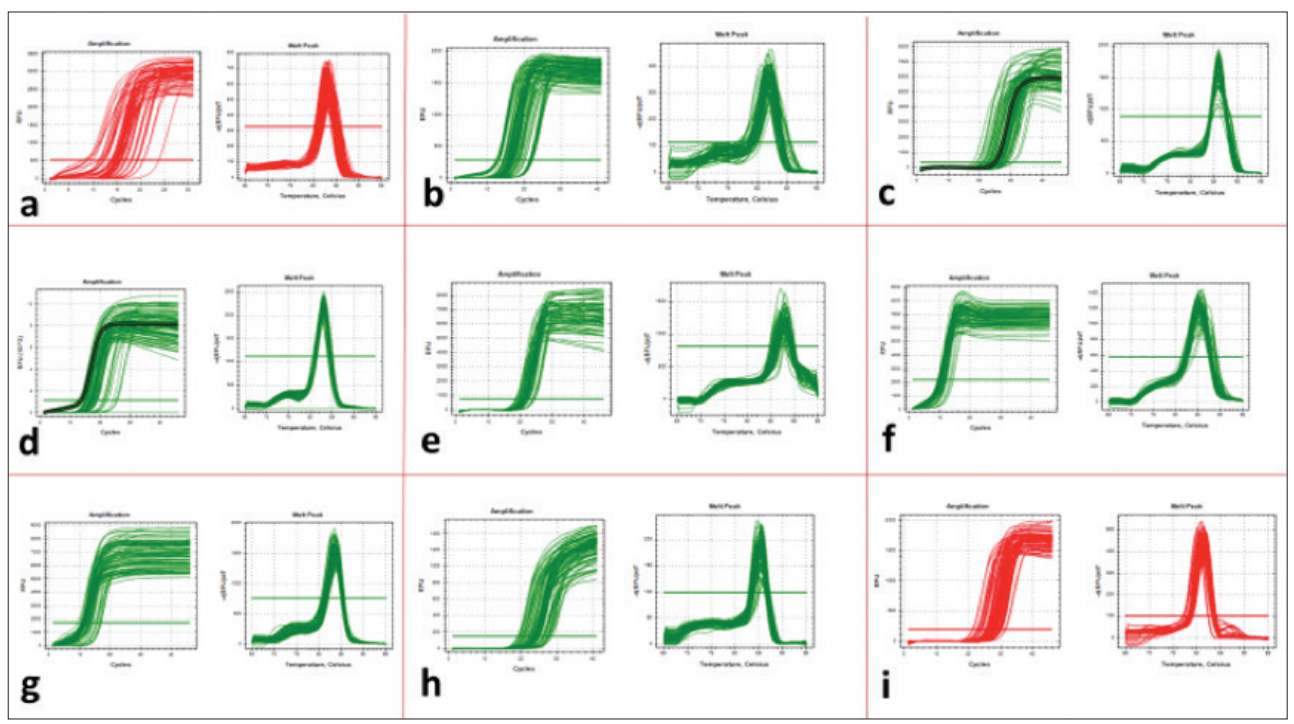

Şekil 2. Kantitatif gerçek zamanlı polimeraz zincir reaksiyonu ( $($ RT-PCR) amplifikasyon ve erime eğrisi görselleri. Her qRT-PCR programı sonuna erime eğrisi analizi eklendi ve aynı noktada Tm değerleri alındı.

a. Bacteroidetes, b. Firmicutes, c. Enterobacter, d. Lactobacillus, e. Bifidobacterium, f. Universal g. Bacteroides, h. Enterococcus, i. Streptococcus.

sahip değişkenlerin ortalamaları arasındaki fark ise Mann-Whitney $U$ testi ile incelendi. Sayısal değişkenler arasındaki ilişkiyi araşırmak için Spearman korelasyon analizi kullanıldı. Verilerin tanımlayıcı istatistikleri ortalama \pm standart sapma, medyan (minimummaksimum) ve $\mathrm{n}(\%)$ olarak verildi. Tüm istatistiksel analizler, IBM SPSS Statistics 22.0 programında $\alpha=0.05$ anlamlılık düzeyinde ve $\% 95$ güven düzeyinde analiz edildi.

\section{BULGULAR}

Bu çalışmada, FMS tanısı almış 54 hasta ve 36 sağlıklı kontrole ait fekal örnekler toplanmış ve Bacteroidetes, Firmicutes, Enterobacter, Lactobacillus, Bifidobacterium ve Streptococcus açısından mikrobiyomlar incelenmiştir. Her bakteri filumu için hasta-kontrol grupları arasında bulunma yüzdeleri karşıllaştıııldığında Bacteroidetes, Firmicutes ve Bifidobacterium için istatistiksel olarak anlamlı farklılık bulunmuştur (sırasıyla $p=0.004, p<0.001, p=$ 0.005). Buna göre, Bactereoidetes ve Bifidobacterium yüzdeleri hasta grubunda artmış, Firmicutes yüzdesi azalmıştır.

Ek olarak, hastalarda tanı için kullanılan skorlama verileri arasındaki korelasyon incelenmiş ve sonuçlar Tablo II'de verilmiştir. Bu amaçla, fibromiyalji etki anketi "fibromyalgia impact questionnaire (FIQ)", geniş ağrı indeksi "wide pain index (WPI)", semptom şiddet skoru "symptom severity score (SSS)", FIQ skorunun üçüncü (FIQ3) ve dördüncü (FIQ4) sorusu karşılaştırılmıştır. Buna göre, toplam skor ile WPI, SSS ve FIQ3 skorları arasında istatistiksel olarak anlamlı ve pozitif korelasyon saptanmıştır. Şiddet derecesi incelendiğinde, SSS ile FIQ3 skoru ve toplam skor arasında istatistiksel olarak yüksek anlamlı 


\begin{tabular}{|c|c|c|c|c|c|c|}
\hline & & FIQ total skor & WPI & SSS & FIQ3 & FIQ4 \\
\hline \multirow[t]{2}{*}{ FIQ total skor } & $r$ & 1 & $0.479^{* *}$ & $0.802^{* *}$ & $0.728^{* *}$ & $0.788^{* *}$ \\
\hline & $\mathrm{p}$ & & $\mathrm{p}<0.001$ & $\mathrm{p}<0.001$ & $\mathrm{p}<0.001$ & $\mathrm{p}<0.001$ \\
\hline \multirow[t]{2}{*}{ WPI } & $\mathrm{r}$ & $0.479^{* *}$ & 1 & $0.475^{* *}$ & $0.317^{*}$ & $0.538^{* *}$ \\
\hline & $\mathrm{p}$ & $\mathrm{p}<0.001$ & & $\mathrm{p}<0.001$ & .025 & $\mathrm{p}<0.001$ \\
\hline \multirow[t]{2}{*}{ SSS } & $\mathrm{r}$ & $0.802^{\star \star}$ & $0.475^{\star *}$ & 1 & $0.695^{\star \star}$ & $0.752^{\star *}$ \\
\hline & $\mathrm{p}$ & $\mathrm{p}<0.001$ & $\mathrm{p}<0.001$ & & $\mathrm{p}<0.001$ & $\mathrm{p}<0.001$ \\
\hline \multirow[t]{2}{*}{ FIQ3 } & $r$ & $0.728^{* *}$ & $0.317^{*}$ & $0.695^{* *}$ & 1 & $0.681^{* *}$ \\
\hline & $\mathrm{p}$ & $\mathrm{p}<0.001$ & .025 & $p<0.001$ & & $\mathrm{p}<0.001$ \\
\hline \multirow[t]{2}{*}{ FIQ4 } & $r$ & $0.788^{* *}$ & $0.538^{* *}$ & $0.752^{* *}$ & $0.681^{* *}$ & 1 \\
\hline & $\mathrm{p}$ & $p<0.001$ & $\mathrm{p}<0.001$ & $\mathrm{p}<0.001$ & $\mathrm{p}<0.001$ & \\
\hline
\end{tabular}

FIQ: Fibromiyalji etki anketi, WPI: Geniş ağrı indeksi, SSS: Semptom şiddet skoru, p: Spearman korelasyon katsayısının değerleri, r: Korelasyon katsayısı.

*istatistiksel olarak anlamlı değer.

**istatistiksel olarak ileri derecede anlamlı değer.

korelasyon olduğu görülmüştür. Anketten alınan toplam puan arttıkça WPI, FIQ3, FIQ4 ve SSS skorları lineer olarak artmaktadır. Ardından FIQ (Tablo III), WPI ve SSS (Tablo IV) skorları ile bakteri yüzdeleri arasındaki korelasyonlara bakılmışıı. Yalnız WPI skorlaması ile bakteri yüzdeleri arasında istatistiksel olarak anlamlı bir ilişki bulunmuştur. WPI skoru ile Enterobacter $(r=-0.698, p<0.001)$, Bifidobacterium $(r=-0.356, p=0.033)$ ve Streptococcus $(r=-0.356, p=0.033)$ yüzdeleri arasında istatistiksel olarak anlamlı negatif korelasyon bulunmuştur (Tablo IV).

Literatürden seçilen primerlerin özgüllüğü ve uygun erime sıcaklıkları gradiyent PCR yöntemi ile analiz edilmiş ve $\% 2^{\prime}$ lik agaroz jelde görüntülenmiştir.

Her qRt-PCR programı sonuna erime eğrisi analizi eklendi ve aynı noktada Tm değerleri alındı.

Bakteriler arasındaki korelasyonlara bakıldığında ise, Bacteroidetes ve Firmicutes yüzdeleri arasında istatistiksel olarak yüksek anlamlı ve negatif korelasyon bulunmuştur ( $r=$ $-0.778, p<0.001)$. Buna göre, Bacteroidetes yüzdesi yüksek çıkan hastalarda Firmicutes yüzdelerinin azaldığı tespit edilmiş̧ir. Aynı zamanda Enterobacter ile Bifidobacterium yüzdeleri arasında $(r=0.460, p=0.005)$, Lactobacillus ile Firmicutes yüzdeleri arasında $(r=$ $0.347, p=0.038)$, Streptecoccus ile Enterobacter yüzdeleri arasında $(r=0.334, p=0.047)$ ve Bifidobacterium ile Streptococcus yüzdeleri arasında $(r=0.354, p=0.034)$ istatistiksel olarak anlamlı pozitif korelasyonlar tespit edilmiştir.

FMS tanılı hastaların cinsiyet ve yaş durumuna göre bakteri yüzdeleri ile ağrı skorları (WPI ve SSS) karşılaştıııldığında ise Tablo V'teki sonuçlara ulaşılmışır. Buna göre, cinsiyete göre bakteri yüzdeleri ve WPI, SSS skorlamaları arasında istatistiksel olarak anlamlı 


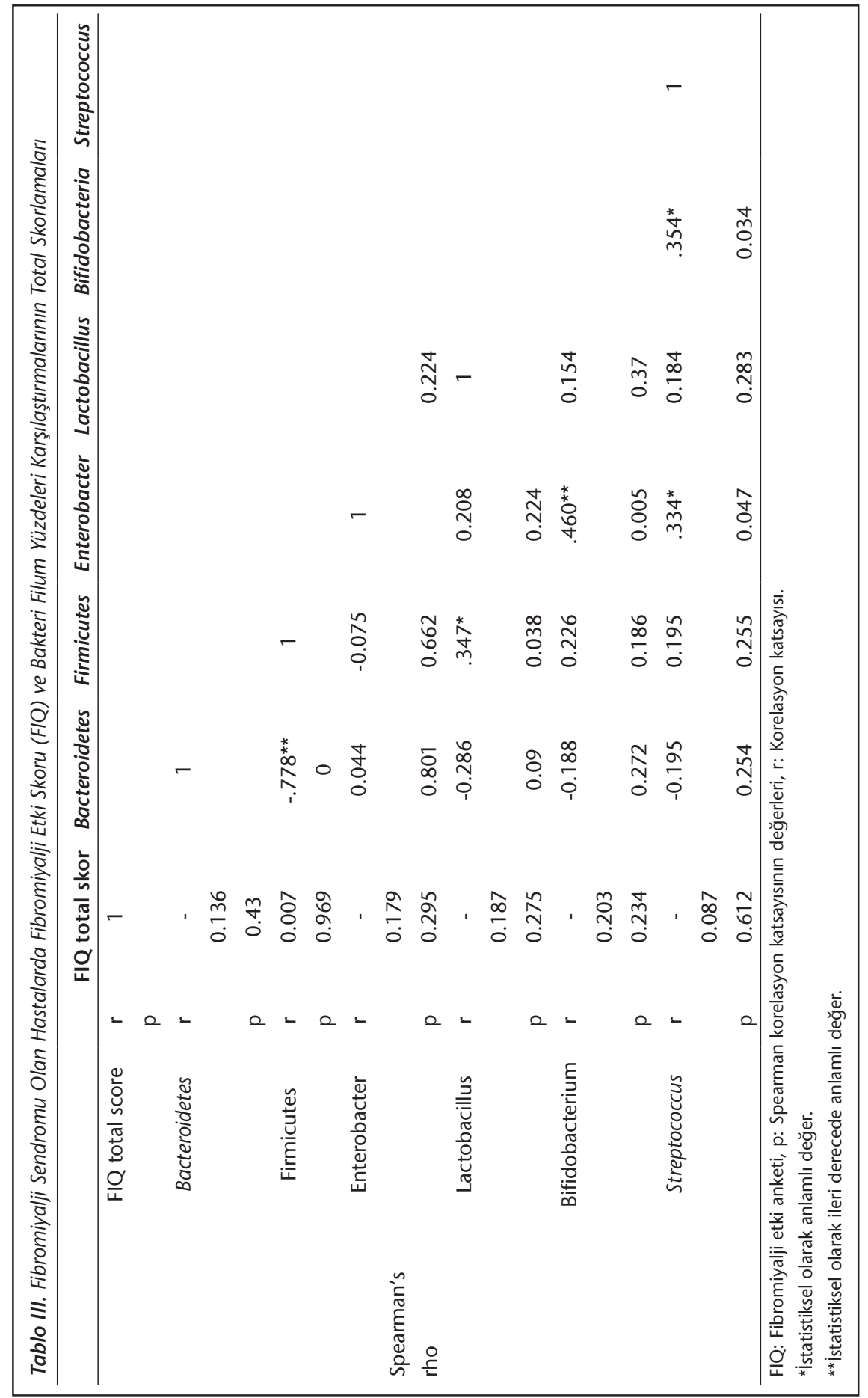




\begin{tabular}{|c|c|c|c|c|}
\hline & & & WPI & SSS \\
\hline \multirow[t]{12}{*}{ Spearman's rho } & Bacteroidetes & $\mathrm{r}$ & .164 & .003 \\
\hline & & $p$ & .340 & .985 \\
\hline & Firmicutes & $r$ & -.012 & -.006 \\
\hline & & $p$ & .943 & .973 \\
\hline & Enterobacter & r & $-.698^{* *}$ & -.086 \\
\hline & & $p$ & $\mathrm{p}<0.001$ & .619 \\
\hline & Lactobacillus & $r$ & -.322 & -.067 \\
\hline & & $p$ & .056 & .697 \\
\hline & Bifidobacterium & $r$ & $-.356^{*}$ & -.085 \\
\hline & & $p$ & 0.033 & .621 \\
\hline & Streptococcus & $r$ & $-.356^{*}$ & .085 \\
\hline & & $\mathrm{p}$ & 0.033 & .624 \\
\hline
\end{tabular}

WPI: Geniş Ağrı İndeksi, SSS: Semptom şiddet skoru, p: Spearman korelasyon katsayısı değerleri, r: Korelasyon katsayısı.

*istatistiksel olarak anlamlı değer.

**istatistiksel olarak ileri derecede anlamlı değer.

Tablo V. Araştırma Sonuçlarının Cinsiyete Göre Karşılaştııılması

\begin{tabular}{|c|c|c|c|}
\hline \multicolumn{4}{|c|}{ Cinsiyet } \\
\hline & Kadın & Erkek & $\mathbf{p}$ \\
\hline Bacteroidetes & $23.57 \pm 11.169$ & $18.25 \pm 15.525$ & $0.447^{*}$ \\
\hline Firmicutes & $23.54 \pm 11.256$ & $24.976 \pm 15.980$ & $0.839^{*}$ \\
\hline Enterobacter & $0.13(0-21.47)$ & $0.002(0.001-0.333)$ & $0.220^{* *}$ \\
\hline Lactobacillus & $0.007(0-0.455)$ & $0.003(0.002-0.010)$ & $0.705^{* *}$ \\
\hline Bifidobacteria & $0.12(0.001-1.853)$ & $0.029(0.011-2.452)$ & $0.665^{* *}$ \\
\hline Streptococcus & $0.004(0-0.08)$ & $0.001(0-0.008)$ & $0.377^{* *}$ \\
\hline WPI & $11.57 \pm 3.648$ & $14.66 \pm 5.131$ & $0.181^{*}$ \\
\hline SSS & $9(6-12)$ & $7(6-9)$ & $0.144^{* *}$ \\
\hline Toplam puan & $54.05 \pm 9.864$ & $49.19 \pm 0.589$ & $0.009^{*}$ \\
\hline Yaş & $46.63 \pm 11.163$ & $36 \pm 9$ & $0.120^{*}$ \\
\hline $\begin{array}{l}\text { WPI: Geniş ağrı } \\
\text { *Bağımsız t testi } \\
{ }^{* * M a n n-W h i t n e) ~}\end{array}$ & mptom şiddet skoru. & & \\
\hline
\end{tabular}

bir fark bulunmamıştır ( $p>0.05$ ). Toplam puan cinsiyete göre incelendiğinde kadınlarda ortalama ağrı skoru erkeklere oranla istatistiksel olarak anlamlı bir şekilde yüksek tespit edilmiştir $(p=0.009)$. 


\section{TARTIŞMA}

Bağırsak mikrobiyotası ile insan fizyolojisi arasındaki bağlantı düşünüldüğünde, çoğu hastalığın sağlıklı bağırsak mikrobiyotasının bozulmasından kaynaklandığı düşünülmektedir. Bu çalışmada, fibromiyalji ile bağırsak mikrobiyotası arasındaki ilişki, hasta ve sağlıklı bireyler arasındaki Bacteroidetes, Firmicutes, Enterobacter, Lactobacillus, Bifidobacterium ve Streptococcus bakteri yüzdeleri incelenerek araştırılmıştır.

Sağlıklı yetişkinlerde tanımlanan fekal mikrobiyotanın \%80'i üç baskın filumda sınıflandırılabilir: Bacteroides, Firmicutes ve Actinobacteria. Genel anlamda, Firmicutes/Bacteroides oranı, insan bağırsak mikrobiyotası bileşimiyle önemli ölçüde ilişkili kabul edilmektedir ${ }^{23}$.

Firmicutes filumu Catenibacterium, Clostridium, Eubacterium, Dorea, Faecalibacterium, Lactobacillus, Roseburia, Ruminococcus ve Veillonella dahil olmak üzere 200'den fazla farklı cinsten gram-pozitif organizmaları içerirken, Bacteroidetes filumu Bacteroides, Odoribacter, Prevotella ve Tannerella dahil olmak üzere yaklaşık 20 cins gram-negatif mikroorganizmayı içerir ${ }^{24}$.

Bağırsaktaki Firmicutes ve Bacteroidetes filumlarının dengesinin bağırsak homeostazı için önemli etkileri olabileceği bilinmektedir ${ }^{25}$. Çeşitli araştırmalar, kronik gastrointestinal hastalıkların beyin iltihabını ve dopaminerjik nöronların ölümünü uyardığını göstermiş$\operatorname{tir}^{26,27}$. Bu durum göz önüne alındığında bağırsak mikrobiyotasındaki değişikliklerin FMS patogenezinde rol oynadığı düşünülebilir. Ayrıca FMS'de; mide-bağırsak şikayetleri, karın ağrısı/krampları, ishal, kabızlık, IBS hastalığa eşlik eder ve IBS prevalansı \%30-35 ile \%70 arasında değişmektedir. FMS'nin etiyopatogenezinde azalmış dopamin ve metabolitlerin de rol oynadığı bilinmektedir ${ }^{28}$.

Bu çalışmanın hipotezi, bağırsak mikrobiyomunda gerçekleşen değişikliklerin FMS etiyopatogenezinde etkili olduğu yönündedir. Bu durum, hastalarda gastrointestinal şikayetleri açıklayabilir ve değişen mikrobiyota kompozisyonu vagal sinir yoluyla beyin omurilik sıvısında (BOS) dopamin, norepinefrin ve serotonin metabolitlerininin seviyesini etkileyebilir.

Hayvan çalışmaları, bağırsakta bulunan mikroorganizmaların vagus sinirini uyarabildiğini ve bu aktivasyonun beyin ve davranışsal etkilerin düzenlenmesinde oldukça kritik bir rol oynadığını göstermiştir. P maddesi, bağırsak-beyin ekseni ile etkileşimde olan önemli bir nöropeptittir ${ }^{29,30}$. P maddesi gibi mikrobiyota ile bağırsak-beyin ekseninde yer alan diğer nöropeptitlerin özgül işlevleri henüz tam olarak bilinmese de, kalsitonin ile ilişkili peptit, nöropeptit Y (NPY), vazoaktif intestinal polipeptit, somatostatin ve kortikotropin salgılama faktörünün (CRF) bu konuda önemli rol oynamaya aday olduğu düşünülmektedir $^{31}$.

Gastroenterolojik, metabolik, romatolojik, nörolojik ve psikiyatrik bozukluklar dahil olmak üzere çok sayıda patolojinin bağırsak mikrobiyomundaki değişikliklerle ilişkili olduğu bildirilmiştir. Ayrıca, son yapılan çalışmalar bağırsakta lokalize bakterilerin kronik ağrıda ve özellikle fibromiyaljide rol oynayabileceğini göstermiştir ${ }^{32}$. Minerbi ve arkadaşları ${ }^{33}$, 
FMS hastalarından alınan fekal örneklerde tüm genom dizileme analizi yöntemiyle geniş kapsamlı bir araştırma yapmış ve FMS'de bağırsak mikrobiyomunun değiştiğine dair kanıtlar sunmuşlardır. IBS'li hastalarda yapılan geniş çaplı bir araştırmada, sağlıklı kontrollere kıyasla IBS'de Firmicutes oranının arttığı, Bacteroidetes oranının azaldığı ve dolayısıyla

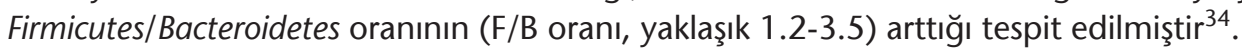

Diğer taraftan, yüksek Firmicutes ve düşük Bacteroides oranının, genellikle sağlıklı ve çeşitli bir mikrobiyomla ilişkili olduğu bilinmektedir ${ }^{23}$. Bu açıdan bakıldığında, çalışmamızda FMS'li hastalarda sağlıklı kontrollere oranla düşen Firmicutes ve artan Bacteriodetes oranı bağırsak mikrobiyom dengesinin olumsuz yönde değiştiğini göstermektedir. Ek olarak, bulgularımız FMS'de bağırsak disbiyozu olduğunu ve mikrobiyota kompozisyonunun değiştiğini göstermesi açısından önemlidir.

Güncel bir çalışmada, sağlıklı kontrollere oranla majör depresif bozukluğu bulunan hastalarda Firmicutes oranının oldukça düştüğü gösterilmiştir ve bu durumun kısa zincirli yağ asitlerinin beyindeki enflemasyonu tetiklemesi nedeniyle olabileceği düşünülmüştür ${ }^{35}$. FMS hastalarında, IBS dışında dirençli yorgunluk, uyku bozuklukları, bilişsel bozukluklar ve duygudurum bozukluğu bulgularını göz önüne alırsak düşük Firmicutes oranı anlamlı olabilir.

Bacteroidetes türleri normalde sağlıklı bağırsak florasında bulunur. Ancak iyi huylu kommensal yaşayan bazı bakteri türlerinin bu ortaklık sırasında bazı etkenler nedeniyle önemli morbidite ve mortaliteye sahip enfeksiyonlardan da sorumlu olabileceği bilinmektedir. Bu durum, bağırsak florasındaki diğer organizmalarla gen paylaşımı ile açıklanabilir. Ayrıca, Bacteriodetes gibi oldukça zengin gen bankasına sahip türlerde, yeni beslenme yolları bulmak, hücreyi toksik substratlardan uzaklaştırmak için dışarı akış pompalarını aktive etmek veya yeni yüzey epitoplarını geliştirmek için bazı genler sonradan aktive edilebilir $^{36}$. Her durumda, sağlıklı mikrobiyom dengesindeki değişimin olumsuz sonuçlar doğurabileceği açıktır.

Ek olarak, sunulan bu çalışmada hasta raporları doğrultusunda hazırlanan ağrı skorlama sistemleri arasında istatistiksel olarak anlamlı pozitif korelasyon ve WPI skorlaması ile bakteri yüzdeleri arasında istatistiksel olarak anlamlı bir ilişki bulunmuştur. Bu durum da FMS'de mikrobiyota etkisini destekler niteliktedir. Ayrıca, skorlama sistemlerinde cinsiyete göre dağılım incelendiğinde, toplam puan bazında kadınlarda ortalama ağrı skorunun erkeklere oranla istatistiksel olarak anlamlı bir şekilde yüksek bulunması literatürle uyumlu ek bir bulgudur.

Bilindiği üzere, bakterilerde ribozomal alt birimler 5S, 16S ve 23 S rRNA'yı içermektedir. Bu rRNA gen dizileri, türler arasında büyük oranda korunmuş olmasına rağmen filogenetik farklılıkları yansıtan değişken bölgeler içermektedir. Özellikle 16S rRNA geni, PCR temelli çalışmalar için korunan alanların ve evrimsel kronometreler olarak hareket eden değişken bölgelerin en izlenebilir kombinasyonunu sağlamaktadır ve bu nedenle filogenetik tanımlamada sıklıkla tercih edilmektedir ${ }^{37}$. 
Bağırsak mikrobiyotasını karakterize etmek için kullanılan en yaygın ve hassas yöntem 16S rRNA'nın yeni nesil dizileme yöntemleri ile analiz edilmesidir. Bu yöntemin avantajları filogenetik sınıflandırmada kantitatif deteksiyon sağlaması, hızlı olması, bilinmeyen bakteriler için de analizin gerçekleştirilebilmesidir; dezavantajları ise PCR kaynaklı teknik sorunların görülmesinin yanı sıra, zahmetli ve pahalı olması ve veri analizi gerektirmesidir ${ }^{37}$.

Yaygın kullanılan diğer bir yöntem ise, kantitatif PCR temelli 16S rRNA'nın amplifikasyonudur. Bu çalışmalarda çift zincire bağlanan çeşitli floresan boyalar kullanılarak (örn. SYBR Green) gerçek zamanlı olarak amplifikasyon izlenebilir. Bu yöntemin avantajı hızlı ve uygun maliyetli bir şekilde kantitatif olarak filogenetik saptama yapmasıdır ancak yine PCR nedenli aksaklıkların olacağı ve bilinmeyen bakterilerin tespit edilemeyeceği, hedefe yönelik çalışma gerektirdiği göz önünde bulundurulmalıdır.

qRt-PCR çalışmalarında göreceli veya mutlak kantifikasyon analiz yöntemleri uygulanabilmektedir. Mutlak kantifikasyonda pozitif kontrol aracılığıyla bir standart eğri çizilerek bulunan Ct değerleri bu standarta göre işlenmekte ve hedef genin tam kopya konsantrasyonu belirlenmektedir. Göreceli kantifikasyonda ise, hedef gen ile bir referans gen de analiz edilerek Ct değerlerini normalize edecek bir kalibratör hesaplanmakta ve kalibratöre göre bir numunedeki hedef gen miktarı belirlenmektedir. Lee ve arkadaşları ${ }^{38}$, 165 rRNA'nın amplifikasyon sonuçlarını hem göreceli hem de mutlak yöntemlerle karşılaştırmış ve her iki yöntemin avantaj/dezavantaj durumuna rağmen benzer sonuçlar sergilediğini göstermiştir. Dolayısıyla mikrobiyota çalışmalarında her iki yöntemde de tercih edilebilir ancak pozitif kontrol olarak bilinen bir örneğin kullanılması çalışmanın hassasiyeti için ön koşuldur.

Bu çalışmada görece uygun maliyeti, uygulama kolaylığı ve hızlı sonuç vermesi nedeniyle kantitatif PCR yöntemi tercih edilmiştir. Ancak çalışmamızın en önemli kısıtlılığı göreceli kantifikasyon uygulanırken pozitif kontrol kullanılmamasıdır. Burada, 16S rRNA amplifikasyonu aracılığılla hedef bakteri miktarı total bakteri miktarına oranlanarak dolaylı yoldan kantifikasyon yapılmıştır ve bu durum ileri konfirmasyonlar gerektirmektedir. Bir diğer kısıtlılık ise bakterilerin filum düzeyinde incelenmiş olmasıdır. Çalışmamız filum düzeyinde genel manzarayı sunmaktadır; türe özgü analizler yapılmamıştır. Bu nedenle FMS kliniğine yönelik bir yorum yapmak doğru olmayacaktır. Bu eksiklikler verilerimizin hassasiyetini azaltmakla birlikte ileride gerçekleştirilecek olası farklı tekniklerle türe özgü çalışmaların önünü açması bakımından önemli bulgular içermektedir.

Sonuç olarak, çalışmamızda Bacteriodetes, Firmicutes ve Bifidobacterium filumları ile FMS arasında anlamlı ilişki bulunmuştur. Daha çok sayıda bireyi içeren kohortlarda yeni nesil dizileme teknolojileri kullanılarak yapılacak kapsamlı ve ileri araştırmalar fibromiyalji ile mikrobiyota ilişkisini daha çarpıcı bir şekilde ortaya çıkarabilir ve olası tedavi seçeneklerini değerlendirmede yol gösterici olabilir.

\section{TEŞEKKÜR}

Entelektüel katkıları ve yardımları için tıbbi biyolog Doç. Dr. Emrah Yücesan'a teşekkürlerimizi sunarız. 


\section{ETIK KURUL ONAYI}

$\mathrm{Bu}$ çalışma, Bezmialem Vakıf Üniversitesi Girişimsel Olmayan Klinik Araştırmalar Etik Kurulu onayı ile gerçekleştirildi (Tarih: 16.10.2018, Karar No: 19/252). Helsinki Deklarasyonu'nun etik kurallarına uygun olarak ve tüm katılımcılardan yazılı bilgilendirilmiş onam formları alınarak çalışılmıştır.

\section{ÇIKAR ÇATIŞMASI}

Yazarlar bu makale ile ilgili herhangi bir çıkar çatışması bildirmemişlerdir.

\section{KAYNAKLAR}

1. Bellato E, Marini E, Castoldi F, Barbasetti N, Mattei L, Bonasia DE, et al. Fibromyalgia syndrome: etiology, pathogenesis, diagnosis, and treatment. Pain Res Treat 2012; (2012): 426130.

2. Schwarz MJ, Spath M, Muller-Bardorff H, Pongratz DE, Bondy B, Ackenheil M. Relationship of substance $P$, 5-hydroxyindole acetic acid and tryptophan in serum of fibromyalgia patients. Neurosci Lett 1999; 259(3): 196-8.

3. Russell IJ, Orr MD, Littman B, Vipraio GA, Alboukrek D, Michalek JE, et al. Elevated cerebrospinal fluid levels of substance $P$ in patients with the fibromyalgia syndrome. Arthritis Rheum 1994; 37(11): 1593-601.

4. Bengtsson A, Henriksson KG, Jorfeldt L, Kagedal B, Lennmarken C, Lindstrom F. Primary fibromyalgia. A clinical and laboratory study of 55 patients. Scand J Rheumatol 1986; 15(3): 340-7.

5. Wolfe F, Smythe HA, Yunus MB, Bennett RM, Bombardier C, Goldenberg DL, et al. The American College of Rheumatology 1990 Criteria for the Classification of Fibromyalgia. Report of the Multicenter Criteria Committee. Arthritis Rheum 1990; 33(2): 160-72.

6. Yunus M, Masi AT, Calabro JJ, Miller KA, Feigenbaum SL. Primary fibromyalgia (fibrositis): clinical study of 50 patients with matched normal controls. Semin Arthritis Rheum 1981; 11(1): 151-71.

7. Staud R, Smitherman ML. Peripheral and central sensitization in fibromyalgia: pathogenetic role. Curr Pain Headache Rep 2002; 6(4): 259-66.

8. Staud R, Rodriguez ME. Mechanisms of disease: pain in fibromyalgia syndrome. Nat Clin Pract Rheumatol 2006; 2(2): 90-8.

9. Sugerman DT. JAMA patient page. Fibromyalgia. JAMA 2014; 311(15): 1577.

10. Clauw DJ, Crofford LJ. Chronic widespread pain and fibromyalgia: what we know, and what we need to know. Best Pract Res Clin Rheumatol 2003; 17(4): 685-701.

11. Gracely RH, Petzke F, Wolf JM, Clauw DJ. Functional magnetic resonance imaging evidence of augmented pain processing in fibromyalgia. Arthritis Rheum 2002; 46(5): 1333-43.

12. Stratz T, Samborski W, Hrycaj P, Pap T, Mackiewicz S, Mennet P, et al. [Serotonin concentration in serum of patients with generalized tendomyopathy (fibromyalgia) and chronic polyarthritis]. Med Klin (Munich) 1993; 88(8): 458-62.

13. Wolfe F, Russell IJ, Vipraio G, Ross K, Anderson J. Serotonin levels, pain threshold, and fibromyalgia symptoms in the general population. J Rheumatol 1997; 24(3): 555-9.

14. Erdrich S, Hawrelak JA, Myers SP, Harnett JE. Determining the association between fibromyalgia, the gut microbiome and its biomarkers: A systematic review. BMC Musculoskelet Disord 2020; 21(1):181.

15. Duvallet C, Gibbons SM, Gurry T, Irizarry RA, Alm EJ. Meta-analysis of gut microbiome studies identifies disease-specific and shared responses. Nat Commun 2017; 8(1): 1784.

16. Thurm T, Ablin J, Buskila D, Maharshak N. Fecal microbiota transplantation for fibromyalgia: a case report and review of the literature. Open J Gastroenterol 2017; 7(4): 131-9.

17. Galland L. The gut microbiome and the brain. J Med Food 2014; 17(12): 1261-72. 
18. Wolfe F, Clauw DJ, Fitzcharles MA, Goldenberg DL, Katz RS, Mease P, et al. The American College of Rheumatology preliminary diagnostic criteria for fibromyalgia and measurement of symptom severity. Arthritis Care Res (Hoboken) 2010; 62(5): 600-10.

19. Murri M, Leiva I, Gomez-Zumaquero JM, Tinahones FJ, Cardona F, Soriguer F, et al. Gut microbiota in children with type 1 diabetes differs from that in healthy children: a case-control study. BMC Med 2013; 11: 46 .

20. Nordeste R, Tessema A, Sharma S, Kovac Z, Wang C, Morales R, et al. Molecules produced by probiotics prevent enteric colibacillosis in pigs. BMC Vet Res 2017; 13(1): 335.

21. Obermajer T, Lipoglavsek L, Tompa G, Treven P, Lorbeg PM, Matijasic BB, et al. Colostrum of healthy Slovenian mothers: microbiota composition and bacteriocin gene prevalence. PLoS One 2014; 10(4): e0123324.

22. Picard FJ, Ke D, Boudreau DK, Boissinot M, Huletsky A, Richard D, et al. Use of tuf sequences for genus-specific PCR detection and phylogenetic analysis of 28 streptococcal species. J Clin Microbiol 2004; 42(8):3686-95.

23. Kenyon J CS, Izadi H. A retrospective outcome study of 42 patients with Chronic Fatigue Syndrome, 30 of whom had Irritable Bowel Syndrome. Half were treated with oral approaches, and half were treated with Faecal Microbiome Transplantation. Human Microbiome Journal 2019; 13: 100061.

24. Tremaroli V, Bäckhed F. Functional interactions between the gut microbiota and host metabolism. Nature 2012; 489(7415):242-9.

25. Assas BM, Miyan JA, Pennock JL. Cross-talk between neural and immune receptors provides a potential mechanism of homeostatic regulation in the gut mucosa. Mucosal Immunol 2014; 7(6): 1283-9.

26. Hawkes CH, Del Tredici K, Braak H. Parkinson's disease: a dual-hit hypothesis. Neuropathol Appl Neurobiol 2007; 33(6): 599-614.

27. Zheng LF, Song J, Fan RF, Chen CL, Ren QZ, Zhang XL, et al. The role of the vagal pathway and gastric dopamine in the gastroparesis of rats after a 6-hydroxydopamine microinjection in the substantia nigra. Acta Physiol (Oxf) 2014; 211(2): 434-46.

28. Russell IJ, Vaeroy H, Javors M, Nyberg F. Cerebrospinal fluid biogenic amine metabolites in fibromyalgia/ fibrositis syndrome and rheumatoid arthritis. Arthritis Rheum 1992; 35(5): 550-6.

29. Holzer P, Farzi A. Neuropeptides and the microbiota-gut-brain axis. Adv Exp Med Biol 2014; 817: $195-219$.

30. Morais LH, Schreiber HLt, Mazmanian SK. The gut microbiota-brain axis in behaviour and brain disorders. Nat Rev Microbiol 2020; 19(4): 241-55.

31. Forsythe $P$, Bienenstock J, Kunze WA. Vagal pathways for microbiome-brain-gut axis communication. Microbial endocrinology: the microbiota-gut-brain axis in health and disease: Springer 2014; 817: 115-33.

32. Minerbi A, Fitzcharles MA. Gut microbiome: pertinence in fibromyalgia. Clin Exp Rheumatol 2020; 38 Suppl 123(1): 99-104.

33. Minerbi A, Gonzalez E, Brereton NJB, Anjarkouchian A, Dewar K, Fitzcharles MA, et al. Altered microbiome composition in individuals with fibromyalgia. Pain 2019; 160(11): 2589-602.

34. Duan R, Zhu S, Wang B, Duan L. Alterations of gut microbiota in patients with irritable bowel syndrome based on 16S rRNA-Targeted Sequencing: A Systematic Review. Clin Transl Gastroenterol 2019; 10(2): e00012.

35. Huang Y, Shi X, Li Z, Shen Y, Shi X, Wang L, et al. Possible association of Firmicutes in the gut microbiota of patients with major depressive disorder. Neuropsychiatr Dis Treat 2018; 14: 3329-37.

36. Wexler HM. Bacteroides: the good, the bad, and the nitty-gritty. Clin Microbiol Rev 2007; 20(4): 593-621.

37. Fraher MH, O'Toole PW, Quigley EM. Techniques used to characterize the gut microbiota: a guide for the clinician. Nat Rev Gastroenterol Hepatol 2012; 9(6): 312-22.

38. Lee C, Lee S, Shin SG, Hwang S. Real-time PCR determination of rRNA gene copy number: absolute and relative quantification assays with Escherichia coli. Appl Microbiol Biotechnol 2008; 78(2): 371-6. 